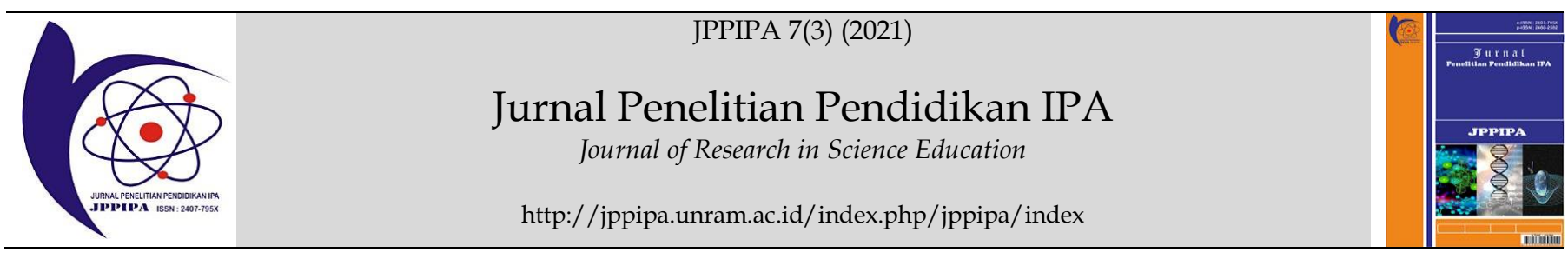

\title{
Development of Earth and Space Knowledge Competencies for Science Teacher Candidates: Field-Project Based Learning Perspectives
}

\author{
An Nuril Maulida Fauziah ${ }^{*}$, Tutut Nurita ${ }^{1}$, M. Arif Mahdiannur ${ }^{1}$, Putri Wahyu Ramadhani ${ }^{1}$
}

${ }^{1}$ Department of Science, Faculty of Mathematics and Natural Sciences, State University of Surabaya, Surabaya, Indonesia.

DOI: $10.29303 /$ ippipa.v7i3.731

\section{Article Info}

Received: May 3th 2021

Revised: July 13'th, 2021

Accepted: July 16 $16^{\text {th }}, 2021$

\begin{abstract}
This study aims to describe the competence of Earth and space knowledge of prospective science teacher students. Learning is carried out with the perspective of FieldProject Based Learning, students are asked to make direct observations of the components of the lithosphere, hydrosphere, and atmosphere in their living environment. Competencies from observations made by students include the ability to determine objects, knowledge of objects, and understanding of objects in their environment. The results of observations carried out are reported in the form of a written report supported by personal documentation in the form of photos of objects (lithosphere, hydrosphere, atmosphere), explanations of the selected objects based on reality connected with references that have been obtained. The results of the study indicate that the ability to determine objects, understanding and knowledge of students is excellent so that learning Earth and Space Sciences is in accordance with Field-Project Based Learning.
\end{abstract}

Keywords: Field-project; Earth and space science; Competencies

Citation: Fauziah, A.N.M., Nurita, T., Mahdiannur, M.A., \& Ramadhani, P.W. (2021). Development of Earth and Space Knowledge Competencies for Science Teacher Candidates: Field-Project Based Learning Perspectives. Jurnal Penelitian Pendidikan IPA, 7(3), 474-480. doi:https://doi.org/10.29303/ippipa.v7i3.731

\section{Introduction}

Natural Sciences is one of the subjects that contains knowledge about natural objects based on exact laws that apply anywhere and anytime (Wikipedia, 2015). Earth and Space Sciences is a branch of Natural Science that studies natural phenomena on Earth and celestial bodies in the solar system and the universe as a whole (Handhita, Akhlis, \& Marwoto, 2016). Learning Earth and Space Sciences covers broad topics that need to be taught to university students, especially to prospective science teacher students who will later become educators at the secondary school level.

As a rich and complex system in interconnection with various knowledge and natural phenomena that occur, Earth and Space Sciences have become a dominant concern in science. Nugent (2008) suggests that IPBA is relevant and useful in life because it can explain observed events and phenomena, especially those that occur on Earth. For example, observations of the lithosphere, hydrosphere, and atmosphere can be explained through inquiry.

Inquiry learning is described from several definitions. One of them is to invite students to activities that can develop knowledge and understanding of concepts as scientists study the natural world. So that students can connect their existing knowledge with evidence or new ideas they get. This inquiry activity is in accordance with IPBA learning, where students learn about the theory and direct observations of phenomena that exist on Earth. This is supported by the opinion of Park (2021), which explains that learning earth and space science should be designed to provide opportunities for students to 
carry out field project activities in order to be able to explore various problems related to the universe.

According to Rozenszayn and Assaraf (2009), project activities in an inquiry-based environment are learning that involves students in direct scientific inquiry activities in nature. Students will be likened to a researcher who will be directly involved in the environmental project activities on an inquiry basis. According to Nation (in Sumarmi, 2012), project-based learning is a pedagogical approach in applying theories, skills, techniques, and real-world solutions. Project-based learning is an approach to constructive learning, namely deepening learning with a researchbased approach to problems and questions that are both real and relevant to life.

Earth and Space Sciences that do not involve field project activities are like science without experiments. Field projects in Natural and space sciences are fundamental. The field of natural and space science research is very wide, covering the entire infinite universe, so that it is said that this universe is a laboratory for natural and space science researchers (Demirkaya \& Atayeter, 2011). Students will be better able to explain natural phenomena through what they experience and see directly. So that students will be more accustomed to learning based on what they do and observe (Mohammed, 2016).

Based on research by Kennedy (2008), learning science and space with field projects can improve student learning outcomes. In addition, the field project activities responded very positively to the students so that the field activities did not feel burdensome. According to (Stokes et al., 2011), the design of fieldwork-based learning activities aims to promote the development of certain ways of thinking and understanding. Therefore, the field-based curriculum design should focus on helping students to acquire increasingly complex and inclusive conceptions through activities that facilitate seeing and experiencing the world in certain ways.

Fieldwork provides a means to actualize students' learning contexts and contribute to student's cognitive development, thereby enabling them to understand relationships between groups of geographic factors (Stokes, Magnier \& Weaver, 2011). According to Hakim et al. (2016), there are significant differences in concept understanding learning outcomes between the group of students treated with project-based learning strategies and groups of students treated with direct learning strategies. Namely, the learning outcomes with applying projectbased learning strategies were higher than those of the project-based learning strategies with direct learning.

Project-based learning provides opportunities for students to work in groups or individually and provides opportunities to develop ideas and realistic solutions so that learning is student-centered instead of teacher-centered (Mohammed, 2016).

Field project-based learning has a variety of cycles and methods. The application of each method is adjusted to the needs of the field research to be carried out. According to Bridle et al. (2016), one of the lessons that can be applied in field project-based learning is Detailed Learning. The learning objectives include inspiring researchers to be directly involved in problem-solving in each of their respective fields, developing expertise and skills, and giving students the opportunity to discuss what they will do and its impact on their daily lives.

Based on the description above, it can be seen that learning natural sciences really needs field project activities in order to support students' knowledge about the universe itself. The purpose of this research is to describe students' ability to determine objects and understanding objects of observation (lithosphere, hydrosphere, and atmosphere) in their environment. Students conduct research around their environment because learning is currently still using the distance learning system due to the Covid-19 pandemic in Indonesia.

\section{Method}

The research was conducted using a qualitative descriptive method by describing students' abilities in determining objects and understanding in field-projectbased learning. The ability to determine objects and understanding in field-project-based learning is assessed based on the research reports of each group of students. Educators or lecturers also provide response questionnaires to assess student responses regarding field-project-based learning.

Research is carried out online and offline, where online research is carried out during lectures on Earth and Space Sciences, and offline research is carried out in the environment where each student lives. The research subjects involved three lecturers of science majors and 70 students of 7 th-semester science teacher candidates who took Earth and space science courses (as seen in diagram 1).

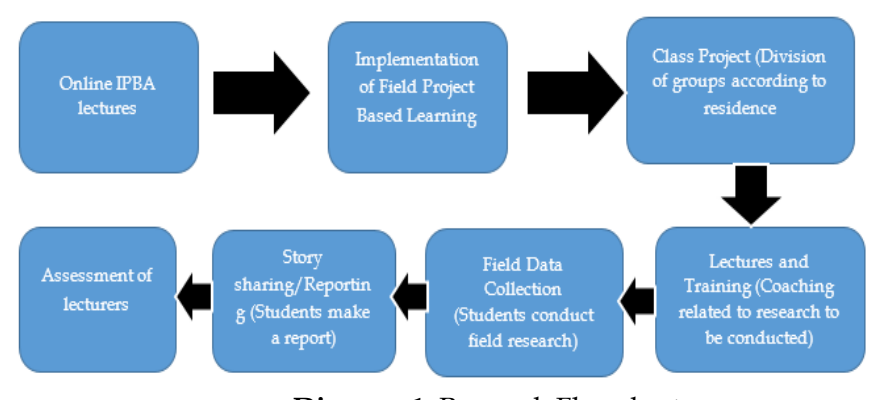

Diagram 1. Research Flowchart 
This study uses field-project-based learning with a detailed-learning concept by Bridle et al. (2016). Interventions carried out by teaching lecturers are designing field-project-based learning by preparing simple lectures to explain the concepts and objectives of the research as well as preparing worksheets that students will use. Field project-based learning syntax consists of class projects, lecture and training projects, field data collection projects, and story-sharing projects (Park, 2021).

\section{Class Project}

Students form groups based on the environment in which they live in order to facilitate communication and research. Students at this stage also design research plans and determine research objects around their respective environments.

\section{Lectures and Training (Online)}

At this stage, the lecturer gives lectures online and provides information related to field research, data that must be collected, and directions in carrying out research. The lecturer also explains the assessment aspects of the results of the reports that will be made by students so that students are focused on collecting data in the field.

\section{Field Data Collection}

Students conduct field research related to aspects of the lithosphere, hydrosphere, and atmosphere around their environment. Students are expected to be able to answer any research problem formulations and freely conduct research in their respective environments.

\section{Story Sharing (Reporting)}

Students make reports on research results. In this report, lecturers can assess students' skills in fieldwork, ability to determine research objects and their understanding of the objects they observe.

\section{Result and Discussion}

\section{Student Response}

Implementation of Field-Project Based Learning received positive responses from students. Based on Mohammed (2016) research, it was found that changes in attitude or if viewed from the aspect of attitude there was a significant increase. The lecturer observed that students who did Field-Project Based Learning felt very happy. This is also supported by the findings of Fletcher et al. (2003) that effective attitudes, values, and interests can be significantly increased in students through field activities. Students who engage in fieldwork leave the impression of feeling more important, interested, and fun.

The application of project-based learning strategies has a better influence on learning outcomes seen from student learning motivation compared to the application of direct learning strategies. This means that high learning motivation in students will increase interest, potential, and creativity in learning because there is a close relationship between motivation and enthusiasm for learning. According to Schunk et al. (2008), motivation can overcome one's pressure and emphasize a goal.

High learning motivation is positively related to learning outcomes. Students who have high learning motivation will always work hard to succeed without expecting rewards or praise. Students like this have a strong tendency to do something for the satisfaction of that success (Hakim et al., 2016). Abidin (2013) explained that project-based learning is oriented to develop student's learning abilities and skills through a series of activities to plan, carry out research, and produce certain reports framed in one container in the form of a learning project. The results obtained are in line with the opinion of Moursund quoted in Sutirman (2013), which suggests that project-based learning has several advantages, namely increasing student motivation, improving the ability to solve problems, and improving

From the activities carried out, students gain meaning or benefits that can be felt directly from the lessons they follow in their daily lives. Students can be creative, innovate, and develop their own potential in the form of activities and works either individually or in groups. This makes students more enthusiastic about learning earth and space sciences, so they are motivated to continue studying the next material.

Research by Inshasiska (2015) shows that student motivation to work on projects is very strong. It is proven when students have to do research outside of lecture hours. Students remain enthusiastic and feel the learning they are doing is fun because students feel they are researchers. This is very positive in the learning process because it can show that there is a very strong extrinsic motivation from students to complete the project.

Field-project-based learning research is proven to give a positive impression on every student who does it. This is shown in the results of an interview with Park (2021), which states that this learning is very beneficial for the long term because these skills can be developed for future job needs. One of the students also explained that he really enjoyed field-project-based learning and was very helpful in understanding their research subjects related to earth and space science. 
The results of research on motivation show that learning motivation has a major role in learning. Learning motivation in students will affect the formation of students' understanding and skills so that it leads to an increase in expected learning outcomes (Mohammed, 2016).

\section{Ability to Determine Observation Object}

Students' ability to determine objects of observation and understanding is improved. This is supported by the research of Hakim et al. (2016) that project-based learning strategies can improve student learning outcomes both conceptual understanding and motor skills. The learning process provides opportunities for active and creative processes to occur where students can build their understanding and skills to solve problems and carry out project activities.

Project work practices have the potential to improve cognition or conceptual understanding through improved perception, application of classification, analysis of descriptions, and synthesis. In addition to improving cognition, Mohammed (2016) also argues that field-project-based learning can improve student psychomotor through the use of Earth and Space Science course instruments to monitor, manipulate and search for certain research subjects properly.

Based on Sastrika (2013), students' critical thinking skills will be trained if lectures use a projectbased lecture model. This is in line with Turnuklu \& Yesildere research (2007) which concluded that projectbased learning could lead a person to practice and understand complex ways of thinking. Project-based learning can also lead one to know how to integrate it in the form of skills often associated with real life. In addition, project-based learning is able to utilize the search for various sources, critical thinking, and have good problem-solving skills. Students' critical thinking skills can help students improve their conceptual understanding of the subject of their research, and students can observe exactly the research object they will use.

Students' understanding of concepts can be increased with project-based learning models because students understand the material repeatedly. When determining ideas, designing projects, and setting up projects, students practice determining the object of research in the lithosphere, hydrosphere, and atmosphere. When doing projects, students can understand the material that was made to be realized in a research report. Project-based learning models can improve conceptual understanding because students can understand the material repeatedly and solve problems and make decisions quickly.
Based on the results of research by Bridle et al. (2016), it can be seen that field projects improve student learning outcomes and understanding because field project activities provide opportunities for students to learn in-depth about the lithosphere, hydrosphere, and atmosphere conceptually and practically. Students also critically reflect on what they have done and discovered during the field project. Students also look for ways to make connections between theory and facts in the field when they conduct research. So that students can determine various factors that directly affect aspects of the lithosphere, hydrosphere, and atmosphere. That way, students will easily determine the object of research around their homes (Park, 2021).

\section{Inquiry Ability}

Field-project-based learning supports learning so as to improve students' inquiry abilities. This is because the syntax of field-project-based learning demands students to be able to find a way to determine the object of their own research independently. The National Science Education Standards state that inquiry is an activity carried out by students in making observations, asking questions, finding sources of information, analyzing and interpreting data, explaining, predicting, and communicating the results (Handriani et al., 2017).

Llwellyn (in Kristanto \& Susilo, 2015) also defines inquiry as a scientific process in an investigation where logic, critical thinking, and individual interest are needed. In the first stage, namely the class project, students form groups according to their respective regions of origin and read the initial research guide from the lecturer with their group. At this stage, students begin to think about the research activities they will do by making research plans and research object plans. Here the lecturer can see that the students are serious and follow the first stage well.

This is supported by Kuhlthau (2007) that students begin to be able to investigate ideas from various sources and integrate these ideas into their own knowledge. They are also beginning to prepare to form a focused perspective on the information-seeking process that they can develop to share and apply through inquiry.

The second phase of Lectures and Training was conducted by 3 lecturers who studied Earth and Space Sciences online. Students are actively involved in this activity because at this stage, the lecturer explains in detail the activities that will be carried out by students, starting from the purpose of the activity to the steps of the activities that students will carry out. Lecturers also explain the assessment criteria in student research so that students are directed in carrying out independent research. 
This stage is reinforced by the results of Furtak's (2006) research that students are actually able to carry out their own observations or investigations, but direction and guidance from lecturers are also needed to convince students that they are able to develop their own knowledge. These lectures and training are carried out online because university-level learning is still using the remote system due to the unfinished pandemic.

In the third stage, namely Field Data Collection, at this stage students act like real scientists. Students conduct research independently with their groups in observing the lithosphere, hydrosphere, and atmosphere in the environment around where they live. In determining the object of research, of course, students are armed with preliminary knowledge about the lithosphere, hydrosphere, and atmosphere from lectures on Earth and Space Sciences by lecturers so that students are able to determine the right research object. At this stage, students actually apply the principle of inquiry where they identify problems independently to collect data according to the sequence of inquiry syntax (Kristanto \& Susilo, 2015). At this stage, students carry out activities and look for every aspect of observation for each object of research, namely the lithosphere, hydrosphere, and atmosphere.

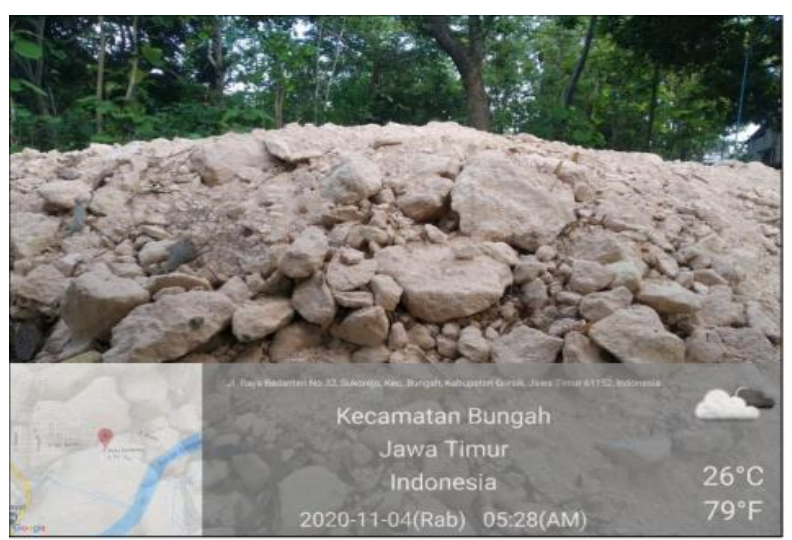

Figure 1. Lithosphere Research Results

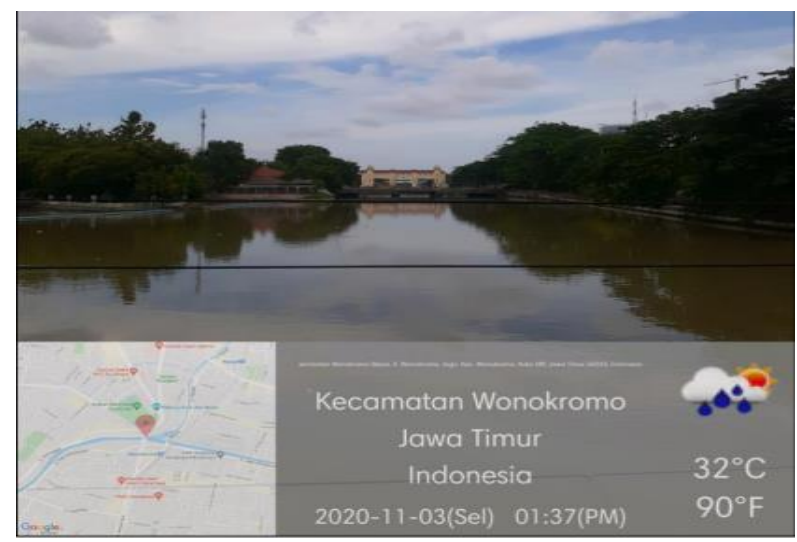

Figure 2. Hydrosphere Research Results

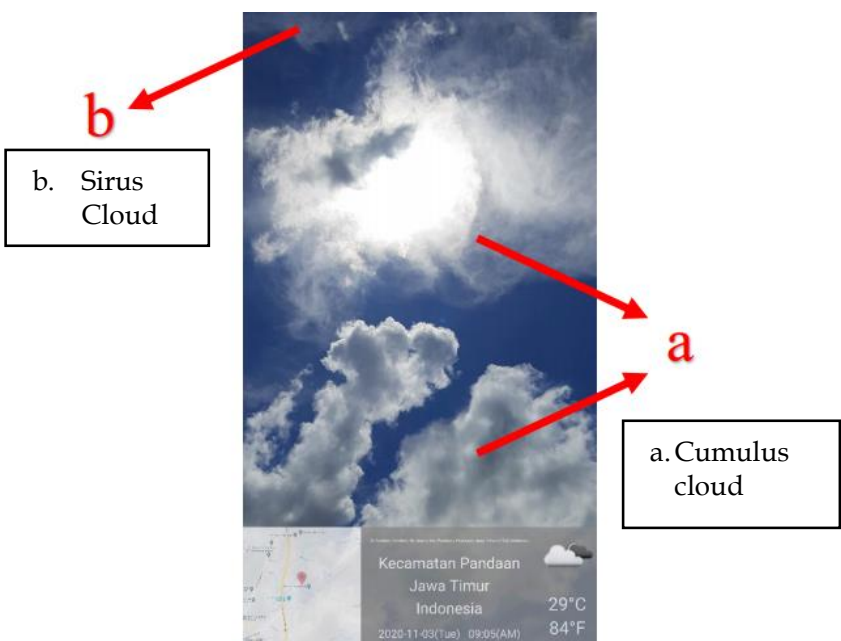

Figure 3. Atmospheric Research Results

Students collect data and make reports on research results according to the worksheets provided by the lecturer during lectures. At this stage, the lecturer only monitors and observes the performance of the students and provides simple feedback. It can be seen that field-project based learning is suitable in increasing student inquiry because the learning involves students actively seeking or investigating an object or a problem systematically, critically, logically, analytically through various sources so that they can find their own research objects and solve it (Warianti et al., 2019).

\section{Conclusion}

Based on the research that has been done, it can be concluded that the implementation of Field-Project based learning in the study of Earth and Space Sciences makes students able to determine objects that are components of the lithosphere, hydrosphere and atmosphere in their neighborhood so that the understanding of student concepts is also better. FieldProject based Learning implementation certainly also supports learning for the development of student inquiry skills.

\section{References}

Abidin, Y. (2013). Desain Sistem Pembelajaran dalam Konteks Kurikulum 2013. Bandung: PT. Refika Aditama. [Indonesian]

Bridle, H., Morton, J., Cameron, P., Desmulliez, M. P. Y., \& Kersaudy-Kerhoas, M. (2016). Design of problem-based learning activities in the field of microfluidics for 12- to 13-year-old participants-Small Plumbing!: empowering the next generation of microfluidic engineers. 
Microfluidics and Nanofluidics, 20(7), 103. https://doi.org/10.1007/s10404-016-1770-x.

Demirkaya, H., \& Atayeter, Y. (2011). A study on the experiences of university lecturers and students in the geography field trip. Procedia - Social and Behavioral Sciences, 19, 453-461. https://doi.org/https://doi.org/10.1016/j.sbspr o.2011.05.154.

Fletcher, S., France, D., Moore, K., \& Robinson, G. (2002). Fieldwork Education and Technology: A GEES Perspective. Planet, 7(1), 17-19. https://doi.org/10.11120/plan.2002.00070017.

Furtak, E. 2006). The Problem Alt Answers: An Exploration of Guided Scientific Inquiry Teaching. Journal of Science Education Vol 90 (3) : 453-467.

Hakim, A., Setyosari, P., Degeng, N., \& Kuswandi, D. (2018). Pengaruh Strategi Pembelajaran (Pembelajaran Berbasis Proyek VS Pembelajaran Langsung) dan Motivasi Belajar. JINOTEP (Jurnal Inovasi dan Teknologi Pembelajaran): Kajian dan Riset Dalam Teknologi Pembelajaran, 3(1), 1-13. doi:http://dx.doi.org/10.17977/um031v3i12016 p001. [Indonesian]

Handhita, E. T., Akhlis, I., \& Marwoto, P. (2016). Pengembangan Media Pembelajaran Materi Astronomi Berbasis Visual Novel Ren'py. Jurnal Pendidikan Fisika, Vol. 5 (1) : 35-41. doi: https://doi.org/10.15294/upej.v5i2.13617 [Indonesian]

Handriani, L. S., Harjono, A., \& Doyan, A. (2017). Pengaruh Model Pembelajaran Inkuiri Terstruktur dengan Pendekatan Saintifik Terhadap Kemampuan Berpikir Kritis dan Hasil Belajar Fisika Siswa. Jurnal Pendidikan Fisika Dan Teknologi, 1(3), 210-2015 doi: https://doi.org/10.29303/jpft.v1i3.261

[Indonesian]

Insyasiska, D., Zubaidah, S., Susilo, H. (2015). Pengaruh Project Based Learning terhadap Motivasi Belajar, Kreativitas, Kemampuan Berpikir Kritis, dan Kemampuan Kognitif Siswa pada Pembelajaran Biologi. Jurnal Pendidikan Biologi, Vol. 7 (1): 9-21. doi: http://dx.doi.org/10.17977/um052v7i1p921 [Indonesian]

Kennedy, W. J. (2008). Relationship Between Field Work and Performance in The Teaching and Learning of Geography in Kiminini Division Trans-Nzoia County, Kenya. In Thesis. Kenyatta University.

Kristanto, Y., \& Susilo, H. (2015). Pengaruh Model Pembelajaran Inkuiri Terbimbing Terhadap Kemampuan Berpikir Kritis Dan Hasil Belajar IPA Siswa Kelas VII SMP. Jurnal Pendidikan Dan Pembelajaran Universitas Negeri Malang, 22(2),
197-208.

Retrieved

from:

http://journal.um.ac.id/index.php/pendidikandan-pembelajaran/article/view/7750

[Indonesian]

Kuhlthau, C. C. (2007). Guided Inqury. London: Libraries Unlimited.

Mohammed, N. (2016). Assessing the Implementation of Fieldwork in the Teaching of Geography in Some Senior Secondary Schools in Kano, Nigeria. IOSR Journal of Humanities and Social Science, 21, 5-11. https:// doi.org/10.9790/0837-2108030511

Nugent, R. (2008). Chronic Diseases in Developing Countries. Annals of the New York Academy of Sciences, 1136(1), 70-79. https://doi.org/https://doi.org/10.1196/annals .1425 .027 .

Nurhidayati, T. (2019). Upaya Meningkatkan Motivasi Belajar dan Pemahaman Konsep melalui Model Pembelajaran berbasis Proyek. Basic Education, 9(8). Retrieved from: http://journal.student.uny.ac.id/ojs/index.php $\angle$ pgsd/article/view/15041 [Indonesian]

Park, Y. M. (2021). A GPS-Enabled Portable Air Pollution Sensor and Web-Mapping Technologies for Field-Based Learning iIn Health Geography. Journal of Geography in Higher Education, 1-21, doi: https://doi.org/10.1080/03098265.2021.1900083.

Rozenszayn, R., \& Ben-Zvi Assaraf, O. (2011). When Collaborative Learning Meets Nature: Collaborative Learning as a Meaningful Learning Tool in the Ecology Inquiry Based Project. Research in Science Education, 41(1), 123-146. https://doi.org/10.1007/s11165-009-9149-6.

Sastrika, I. A. K., Sadia, I. W., \& Muderawan, I. W. (2013). Pengaruh Model Pembelajaran Berbasis Proyek terhadap Pemahaman Konsep Kimia dan Keterampilan Berpikir Kritis. Jurnal Pendidikan dan Pembelajaran IPA Indonesia. 3(2). Retrieved from: $\quad$ https://ejournalpasca.undiksha.ac.id/index.php/jurnal_ipa/arti cle/view/799 [Indonesian]

Schunk, D. H, Pintrich, P.R., \& Meece, J.L. (2008). Motivation in education: Theory, research, and application $(3 " \wedge$ ed.). Upper Saddle River, NJ:Merrill/Prentice-Hall.

Stokes, A., Magnier, K., \& Weaver, R. (2011). What is the Use of Fieldwork? Conceptions of Students and Staff in Geography and Geology. Journal of Geography in Higher Education, 35(1), 121-141. https://doi.org/10.1080/03098265.2010.487203.

Sumarmi. (2012). Model-Model Pembelajaran Geografi. Malang: Aditya Media Publishing. [Indonesian]

Sutirman. 2013. Media \& Model - model Pembelajaran Inovatif. Yogyakarta: Graha Ilmu. [Indonesian] 
Turnuklu, E. B., \& Yesildere, S. (2007). The Pedagogical Content Knowledge in Mathematics: Preservice Primary Mathematics Teachers' Perspectives in Turkey. IUMPST: The Journal, 1(Content Knowledge), 1-13.

Warianti, A., Rusijono., \& Nasution. (2019). Pengaruh Model Pembelajaran Inkuiri terhadap Kemampuan Berpikir Kritis dan Hasil Belajar Siswa Kelas IV SD pada Subtema Keindahan Alam Negeriku. Jurnal Kajian Pendidikan dan Hasil Penelitian. $5(2)$. doi: http://dx.doi.org/10.26740/jrpd.v5n2.p1019-1024 [Indonesian]

Wikipedia. (2015). Ilmu Alam. (Online). https://id.wikipedia.org/wiki/Ilmu_alam, Retrieved on 21 April 2021). [Indonesian] 